Original Article

\title{
FORMULATION AND EVALUATION OF MICROEMULSION CONTAINING NEEM SEED OIL
}

\author{
YOGESH S. THORAT ${ }^{1}$, NAGESH S. KOTE ${ }^{*}$, VIRENDRA V. PATIL ${ }^{1}$, AVINASH H. HOSMANI ${ }^{2}$
}

${ }^{1}$ Department of Pharmaceutics, D. S. T. S. Mandal's College of Pharmacy, Solapur, Maharashtra, India, ${ }^{2}$ Department of Pharmaceutics, Government College of Pharmacy, Ratnagiri

Email: nageshkote5@gmail.com

Received: 25 Jan 2020, Revised and Accepted: 23 Mar 2020

\begin{abstract}
Objective: The objective of the present study was to formulate Microemulsion containing seed oil. Neem seed (Azadirachtaindica) oil was extracted from its seeds by the soxhlet apparatus. Acetone is used as a solvent. PEG 400 and Carbopol 940p was select as surfactant, co-surfactant and hydrogel thickening agent. Microemulsions were characterized for $\mathrm{pH}$, viscosity, spreadability, in vitro drug transport study and in vivo antibacterial activity and shows satisfactory results. Antibacterial activity of formulation against E. coli Shows at a concentration of $3 \%$. The neem seed oil microemulsion has the potential for antibacterial activity.

Methods: A ratio of surfactant and cosurfactant i.e, S/CoSchoosen and corresponding mixture was made. The mixture was mixed with oil. Each mixture was mixed thoroughly using magnetic stirrer until homogenous dispersion/solution was obtained. Double distilled water was used in this formulations as to prevent the incorporation of surface active impurities. The mixture was titrated with water and ambient temperature with constant stirring at the endpoint where the mixture become clouded, the quantity of aquous phase added. The percentage of three different pseudophases incorporated were calculated.
\end{abstract}

Results: Solubility studies in various solvents reveals that the oil is insoluble in distilled water and ethanol. Soluble in methanol.

Conclusion: It was observed that the microemulsion having multilamellar nature. Batches with carbopol shows better homogenous distribution. The stability of microemulsion prepared with carbopol 71 was gretter than with xanthan gum. The in vitro study of microemulsion was performed and Batch (F7) is optimized batch which shows highest drug release.

Keywords: Neem seed oil, Microemulsion, Topical application, Antibacterial activity

(C) 2020 The Authors. Published by Innovare Academic Sciences Pvt Ltd. This is an open access article under the CC BY license (http://creativecommons.org/licenses/by/4.0/] DOI: http://dx.doi.org/10.22159/ijcpr.2020v12i3.38301. Journal homepage: https://innovareacademics.in/journals/index.php/ijcpr

\section{INTRODUCTION}

Microemulsions are thermodynamically stable isotropically clear dispersion of two immiscible liquids, like oil and water, stabilized by an interfacial film of surfactant molecules, with a size range of 5-200 $\mathrm{nm}$ and have very low interfacial tension [1]. Microemulsions could be an alternative carrier in topical drug delivery and as it has high Solubilization capability and nanometer size, it is believed that microemulsion will be a better candidate in delivering drug topically. They are composed of surfactant, water, and oil having cosurfactants provide better therapeutic action when compared to the traditional cream and lotions [2]

It is a topical delivery in skin, which makes the drug delivery difficult. This factor is consideration of preparation of microemulsions which have low skin irritation, high drug loading capacity, It reduce the diffusion barrier of corneum by dissolving the lipids in the Stratum corneum and enhancing the permeation of drug [3].

Traditionally neem seed oil and leaves used as insect repellent and as pesticides. Neem oil containing Azadirachatin could be used in hair care formulation due to their antiheadche, antidandruff, and antifungal properties [4]. Almost all parts of neem have been used as traditional Ayurvedic, in unani, and siddha medicine in india. Neem oil is used to control various skin infections [5].

The aim of the present study is to formulate topical microemulsion using Neem seed oil, tween 80, PEG 400, xanthan gum, carbopol 940 . Tween 80 is a non-ionic, non-toxic surfactant that is not affected by change in $\mathrm{pH}$. The antibacterial efficacy of the formulated microemulsion is additionally investigated.

\section{MATERIALS AND METHODS}

Table 1: List of chemicals

\begin{tabular}{lll}
\hline S. No. & Chemical & Manufacturer/Provier \\
\hline 1 & Neem seed oil & Pradip aggrotech pvt. ltd \\
2 & Tween 80 & Lab grade \\
3 & Propylene Glycol 400 & Lab grade \\
4 & Carbopol 71 & Lab grade \\
5 & Xanthan gum & Lab grade \\
6 & Ethanol & Lab grade \\
\hline
\end{tabular}

\section{Extraction of neem seed oil [6]}

Neem seeds were washed three times thoroughly till no dust or other impurities left. Neem seeds were heated in a temp of $50{ }^{\circ} \mathrm{C}$ for one hour so they would dry out so kernels can be separated from wooden parts of seeds. The kernels were grounded using grinder. Soxhlet apparatus used for the extraction of neem seed oil. The kernel powder was placed into the soxhlet apparatus. Acetone is used as solvent in the ratio of 1:5 (W/V). The solvent was hated at $50{ }^{\circ} \mathrm{C}$ for eight hours so no oil left in the neem kernel. Then the 
mixture of oil and solvent was kept in room temperature for $48 \mathrm{~h}$ so the solvent evaporates completely and eventually oil is left.

\section{Analysis and characterisation of extracted oil [7] \\ Determination of specific gravity}

The specific gravity of the oil was determined using specific gravity bottle.

\section{Determination of refractive index}

This is physical attribute of triglycerine measures by the angle through which a beam of light is bent when passing through a thin film of melted fat few drops of oil were placed on one face of glass prism of a refractometer and it was gently spread, closed and tightened. Ample time is allowed for the prism and oil to achieve steady temperature. The refractive index was then read from demarcation line.

\section{Determination of $\mathrm{pH}$}

The $\mathrm{pH}$ of oil was determined by using digital $\mathrm{pH}$ meter.

\section{Preparation of standard calibration curve of neem oil [8]}

Different concentrations of Neem oil were prepared with different solvents and scanned in the UV range. The wavelength $220 \mathrm{~nm}$ was selected for neem oil, where it show maximum absorbance. Lower concentrations does not show any absorbance, hence concentration (above $10 \mathrm{mcg}$ ) were taken for calibration. The calibration curves were linear over the concentration range of $30-70 \mathrm{ug} / \mathrm{ml}$ of neem oil. Absorbance versus concentration plotted

\section{Formulation of microemulsion [6]}

A ratio of surfactant and cosurfactanti. e,S/CoSchoosen and corresponding mixture was made. The mixture was mixed with oil. Each mixture was mixed thoroughly using magnetic stirrer until homogenous dispersion/solution was obtained. Double distilled water was used in this formulations as to prevent the incorporation of surface active impurities. The mixture was titrated with water and ambient temperature with constant stirring. At the end point where the mixture become clouded, the quantity of aquous phase added. The percentage of three different pseudo-phases incorporated were calculated. Same procedure was followed for all S/Co ratios. Phase diagrams were prepared after calculating the percentage of each phase required to form microemulsions. After preparing the pseudo ternary phse diagram the medicated microemulsions were formulated.

\section{Evaluation of microemulsion [9]}

\section{Physical appearance}

Prepared microemuisions were observed for color, homogeneity, consistency, texture, and $\mathrm{pH}$.

\section{Spreadability measurement}

The spreadability of the microemulsion was determined by placing $0.5 \mathrm{~g}$ micoemulsion within a pre-marked circle of $1 \mathrm{~cm}$ diameter on a glass plate over which a second glass plate was placed. A weight of 5 $\mathrm{g}$ was allowed to rest on the upper glass plate for five min. The increase in the diameter due to spreading of the microemulsion was noted, and the mean diameter was taken.

\section{Globule size determination}

The globule size of the microemulsion was determined by optical microscope.

\section{Viscosity}

It was determined at $25 \pm 1^{\circ} \mathrm{C}$ by means of Brookfield viscometer.

\section{In vitro skin permeation [10]}

In vitro skin permeation study was performed by using Franz diffusion cells with an effective diffusion area of $2.8 \mathrm{~cm}^{2}$. The excised skin samples of rat were clamped in between donar and receptor compartment of Franz diffusion cell.1g of sample was added to the donar compartment. The receptor compartment was filled with PBS $\mathrm{pH} 7.4$ and maintained at $37{ }^{\circ} \mathrm{C}$ with stirring at $100 \mathrm{rpm}$. At predetermined time of interval $3 \mathrm{ml}$ of sample was withdraw and fresh same quantity of sample was added. Samples were filtered through whatman filter paper and analysed by UV spectrophotometer at $220 \mathrm{~nm}$. The amount of drug permeted per unit surface area $\left(\mu \mathrm{g} / \mathrm{cm}^{2}\right)$ was plotted versus time $(\mathrm{h})$ and the flux $\left(\mu \mathrm{g} / \mathrm{cm}^{2}\right)$ was calculated from slope of the line.

\section{Antimicrobial study [11]}

Antimicrobial test was performed on previously prepared agar plates. On which E. coli saline solution was spread with the help of glass spreader. Wells were prepared with the help of borer, samples were withdrawn with the help of micropipette $(100 \mathrm{ug} / \mathrm{ml})$ and poured into the prepaped wells. Then plates were incubated at $37^{\circ} \mathrm{C}$ for $24 \mathrm{~h}$. And zone of inhibition was measured with the help of scale after $24 \mathrm{~h}$.

\section{RESULTS AND DISCUSSION}

\section{Determination of solubility study}

Solubility studies in various solvents reveals that the oil is insoluble in distilled water and ethanol. Soluble in methanol.

\section{Calibration curve for neem oil}

Calibration curve for Neem seed oil by UV spectrophotometer. The equation found was $\mathrm{Y}=\mathrm{mx}+\mathrm{c}$ and $\mathrm{R}^{2}$ value was 0.9985. The concentration of drug was in the range of $30-70 \mu \mathrm{g} / \mathrm{ml}$.

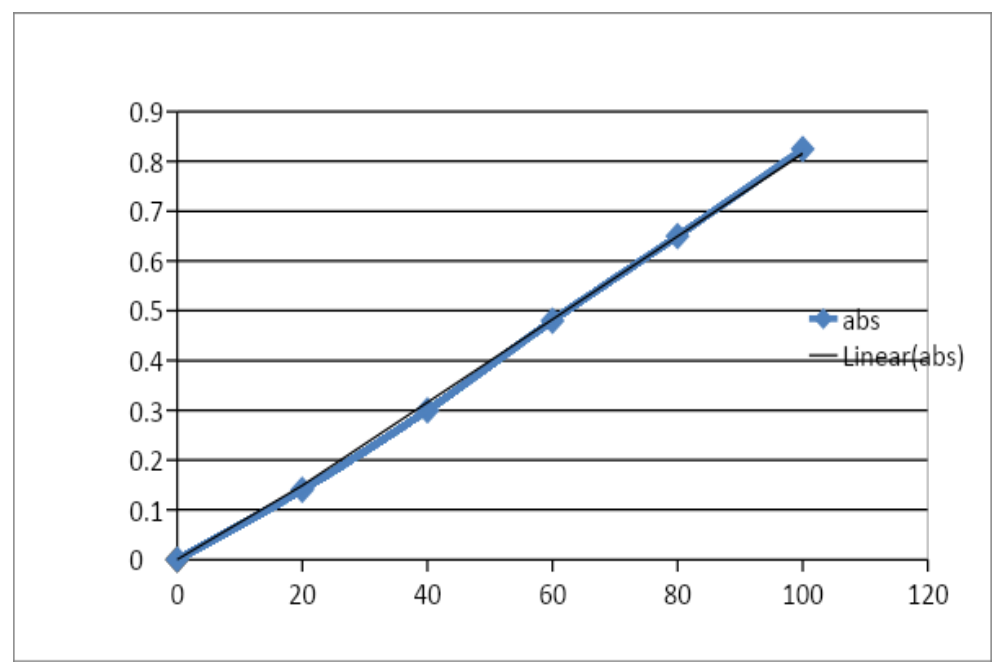

FTIR of neem seed oil 


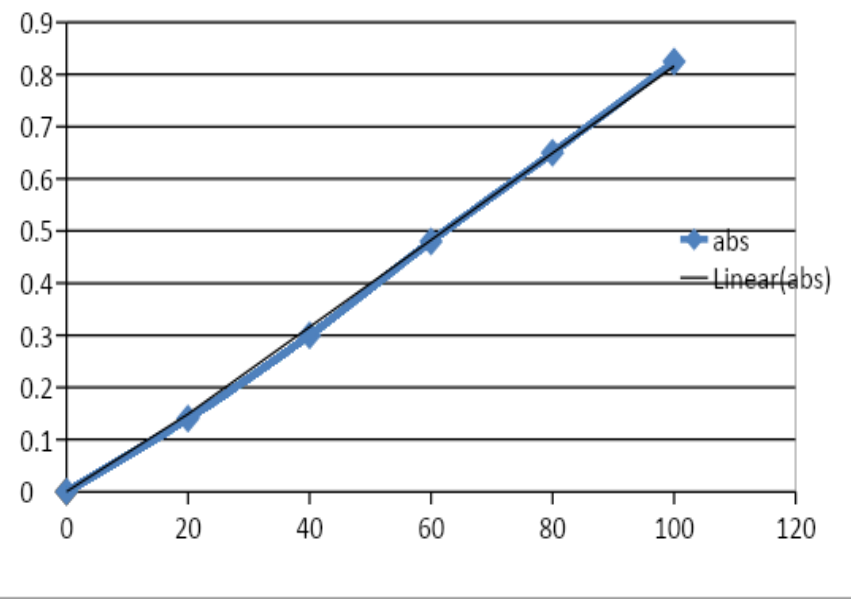

Fig. 1: FTIR of neem seed oil

Table 2: Neem seed oil evaluation

\begin{tabular}{lll}
\hline Property & Experimental value & Unit \\
\hline Refractive index & 1.2564 \\
pH & 5.4 \\
Specific gravity & 0.931 \\
\hline
\end{tabular}

Table 3: Formulation of neem seed oil microemulsion

\begin{tabular}{|c|c|c|c|c|c|c|c|}
\hline Batches & $\begin{array}{l}\text { Stirring time } \\
(1000 \mathrm{rpm})\end{array}$ & Oil & Tween 80 & PEG 400 & Xanthan gum & Carbopol 71 & Water upto $100 \mathrm{ml}$ \\
\hline F1 & $30 \min$ & $10 \%$ & $20 \%$ & $5 \%$ & $0.3 \%$ & - & 100 \\
\hline $\mathrm{F} 2$ & $40 \mathrm{~min}$ & $10 \%$ & $20 \%$ & $5 \%$ & $0.3 \%$ & - & 100 \\
\hline F3 & $50 \mathrm{~min}$ & $10 \%$ & $30 \%$ & $5 \%$ & $0.7 \%$ & - & 100 \\
\hline F4 & $60 \mathrm{~min}$ & $10 \%$ & $30 \%$ & $5 \%$ & $0.9 \%$ & - & 100 \\
\hline F5 & $30 \mathrm{~min}$ & $10 \%$ & $40 \%$ & $5 \%$ & - & $0.3 \%$ & 100 \\
\hline F6 & $40 \mathrm{~min}$ & $10 \%$ & $50 \%$ & $5 \%$ & - & $0.3 \%$ & 100 \\
\hline F7 & $50 \mathrm{~min}$ & $10 \%$ & $50 \%$ & $5 \%$ & - & $0.7 \%$ & 100 \\
\hline F8 & $60 \mathrm{~min}$ & $10 \%$ & $60 \%$ & $5 \%$ & - & $0.9 \%$ & 100 \\
\hline
\end{tabular}

Table 4: Apperence and transparency

\begin{tabular}{ll}
\hline Batches & Appearance and transparency \\
\hline F1 & Cloudy \\
F2 & Cloudy \\
F3 & Clear \\
F4 & Clear \\
F8 & Clear And Transparent \\
F6 & Clear And Transparent \\
F7 & Clear And Transparent \\
F8 & Clear And Transparent \\
\hline
\end{tabular}

Table 5: Globule size determination

\begin{tabular}{llll}
\hline Characters & Globule size (nm) & & \\
\hline Batches & F5 & F6 & \\
\hline$X_{10}$ & 388.54 & 416.15 & \\
$X_{50}$ & 434.51 & 476.31 & 42.29 \\
$X_{90}$ & 497.66 & 574.24 & 48.33 \\
$X_{16}$ & 392.01 & 424.75 & 58.05 \\
$X_{84}$ & 486.73 & 554.01 & 41.09 \\
$X_{99}$ & 544.74 & 654.11 & 57.52 \\
SMD & 438.02 & 487.21 & 42.94 \\
VMD & 431.15 & 491.78 & 44.78 \\
Sv & $12.84 \mathrm{~m}^{2} / \mathrm{cm}^{2}$ & $13.49 \mathrm{~m}^{2} / \mathrm{cm}^{2}$ \\
Polydispersity index & 44.33 & 32.21 & 43.92 \\
\end{tabular}




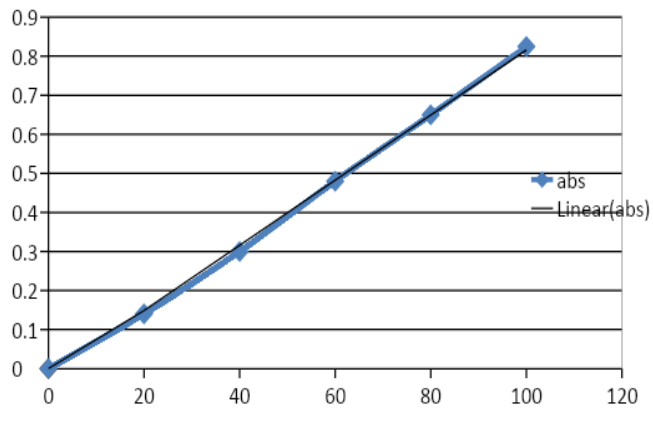

Fig. 2: Globule size determination of batch F5

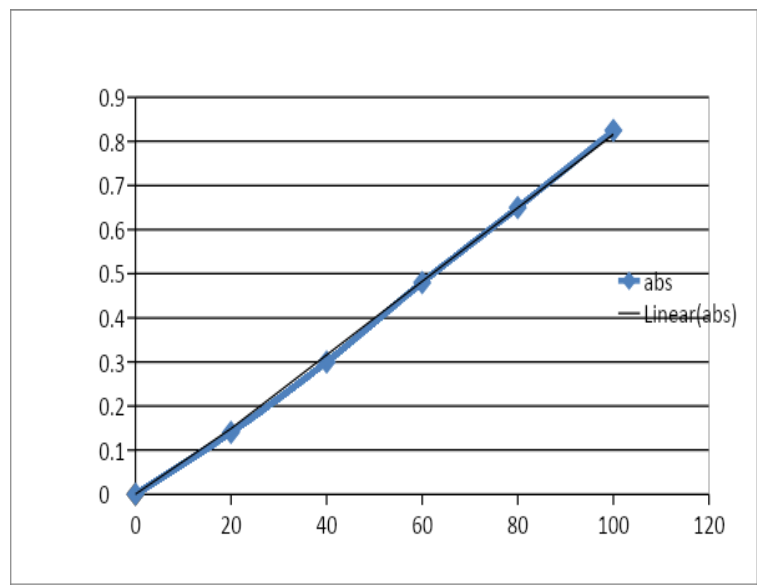

Fig. 3: Globule size determination of batch F6

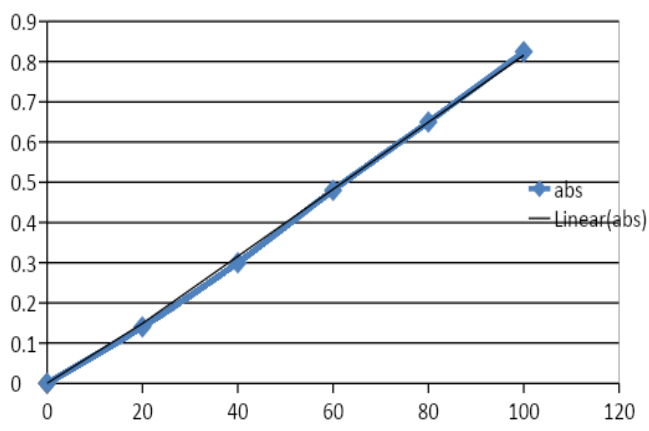

Fig. 4: Globule size determination of batch F7

Table 6: Measurement of pH

\begin{tabular}{lll}
\hline Batches & pH \\
\hline F1 & 6.3 \\
F2 & 7.1 \\
F3 & 7.7 \\
F4 & 7.3 & 7 \\
F8 & 7.8 \\
F6 & 7.4 \\
F7 & 7.1 \\
F8 & & \\
\hline
\end{tabular}


Table 7: Refractive index

\begin{tabular}{ll}
\hline Batches & Refractive index \\
\hline F1 & $1.4440 \pm 0.001$ \\
F2 & $1.4556 \pm 0.002$ \\
F3 & $1.4215 \pm 0.003$ \\
F4 & $1.4362 \pm 0.007$ \\
F8 & $1.4960 \pm 0.003$ \\
F6 & $1.4645 \pm 0.004$ \\
F7 & $1.4645 \pm 0.008$ \\
F8 & $1.4916 \pm 0.001$ \\
\hline
\end{tabular}

Table 8: Viscosity

\begin{tabular}{ll}
\hline Batches & Viscosity cp (spindle speed 0.3) RPM spindle no 63 \\
\hline F1 & 9897 \\
F2 & 10119 \\
F3 & 11325 \\
F4 & 11444 \\
F8 & 11550 \\
F6 & 11230 \\
F7 & 12690 \\
F8 & 11856 \\
\hline
\end{tabular}

Table 9: Spredability

\begin{tabular}{ll}
\hline Batches & Spredability gm. $\mathbf{~ m} / \mathbf{s e c}$ \\
\hline F1 & 2.8 \\
F2 & 2.4 \\
F3 & 2.9 \\
F4 & 3.1 \\
F8 & 3.8 \\
F6 & 3.41 \\
F7 & 3.9 \\
F8 & 3.2 \\
\hline
\end{tabular}

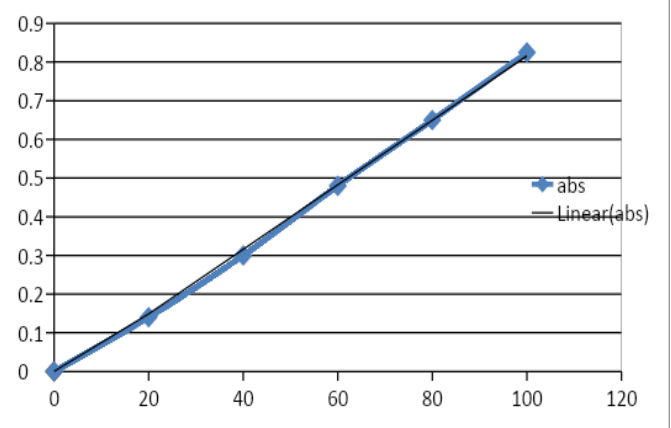

Fig. 5: Antimicrobial activity of neem seed oil 1. Marketed formulation, 2. Neem seed oil microemulsiom, 3. Placebo

\section{Cumulative percent drug release of batch F1-F8}

\section{Antimicrobial activity of microemulsion}

Antimicrobial activity of oil was performed on E. coli. The inhibitory action was showed at concentration of $3 \%$. The seed oil at concentration of $0.3 \%$ on agar plate was found to be active against Staphylococcus Aureus and at $0.4 \%$ was active against Salmonella typhosa. The Neem seed oil was found to be inactive against Pseudomonas aeruginosa.

The bacteria (E. coli) was tested against marketed formulation, as a placebo and with oil.

\section{CONCLUSION}

Neem seed oil microemulsion was prepared in order to enhance skin penetration. Microemulsion were prepared by phase titration method using tween 80 surfactant or PEG 400 as cosurfactant and thickening agent. Neem seed oil as antibacterial agent. It was observed that the microemulsion having multilamellar nature. Batches with carbopol shows better homogenous distribution. It is also depends on stirring time. Batches with carbopol 71 having better viscosity than batches with xantham gum. The stability of microemulsion prepared with carbopol 71 was gretter than with xanthan gum. The in vitro study of microemulsion was performed and Batch (F7) is optimized batch which shows highest drug release. The formulation tested against bacteria (E. coli) and have antimicrobial activity. The bacteria tested against marketed formulation, neem seed oil microemulsion, and as a placebo. Highest zone of inhibition was observed by Neem seed oil microemulsion.

\section{ACKNOLEDGEMENT}

The auther's are thankful to D. S. T. S. Mandals college of Pharmacy Solapur for providing raw materials and necessary facility to carry out this research work successfully. The auther's are also thankful to Dr. Yogesh S. Thoratfor providing timely guidance and assistance. 


\section{FUNDING}

Nil

\section{AUTHORS CONTRIBUTIONS}

All the authors have contributed equally.

\section{CONFLICT OF INTERESTS}

Declare none

\section{REFERENCES}

1. Vidya Sabale, Sejal Vora. Formulation and evaluation of microemulsion-based hydrogel for topical delivery. Int J Pharm Invest 2012;2:141-9.

2. Faizi Muzaffar, UK Singh. Design development and evaluation of topical microemulsion. Int Res J Pharm 2017;8:95-110.

3. Vidya Sabale, Sejal Vora. Formulation and evaluation of microemulsion-based hydrogel for topical delivery. Int J Pharm Invest 2012;2:140-9.
4. Muhammed Majeed, Satyan KS. Neem oil limonoids: product overview; 2007. p. 2-8.

5. Mohammad A. Review on spermicidal activity of azardirachta Indica. J Pharmacol Phytochem 2013;1:61-75.

6. Rodina Sadr Ghotbi, Marziyeh Khatibzadeh, Shadi Kordbacheh Preparation of neem seed oil nanoemulsion. Proceedings of the 5th International Conference on Nanotechnology: Fundamentals and Applications Prague, Czech Republic; 2014;11:1-5.

7. BA Ikyenge, BO Ogenyi. An evaluation of the impact of epoxidized neem seed oil (azadirachtaindica) modification on the adhesive properties of soybean glue. Int J Adv Res Chem Sci 2015;2:1-5.

8. Dubhashi S, Pranay Singaiah M, Prasad V. V studies on extraction and HPLC analysis of azadirachtin from kernels of neem seed. J Adv Pharm Edu Res 2013;3:57-60.

9. Patel J, Trivedi J. Formulation and evaluation of microemulsion based topical hydrogel containimg Lornoxicom. J Appl Pharm Sci 2014;4:625-38.

10. Walekar SS, Wankkhade NB. Microemusion based gel system: anovel approach for topical drug delivery. Int J Adv Pharm Sci 2014;5:1776-82. 